\title{
Leaf and fruiting phenology and gas exchange of Mangabeira in response to irrigation
}

\author{
Francisco de A. Lobo ${ }^{1 *}$, José H. Campelo Junior ${ }^{1}$, Carmen E. Rodríguez-Ortíz ${ }^{2}$, Isabela C. de \\ Lucena $^{2}$ and George L. Vourlitis ${ }^{3}$
}

${ }^{1}$ Universidade Federal de Mato Grosso, Departamento de Solos e Engenharia Rural, Av. Fernando Corrêa da Costa, s/n, Coxipó da Ponte, 78060-900 Cuiabá, Mato Grosso, Brasil. ${ }^{2}$ Universidade Federal de Mato Grosso, Departamento de Botânica e Ecologia, Av. Fernando Corrêa da Costa, s/n, Coxipó da Ponte, 78060-900 Cuiabá, Mato Grosso, Brasil. ${ }^{3}$ California State University, San Marcos, Biological Science Department, San Marcos, CA 92096, USA. *Corresponding author: f_a_lobo@cpd.ufmt.br

Received: 18 October 2007; Returned for revision: 10 December 2007; Accepted: 25 January 2008

The mangabeira (Hancornia speciosa Gómez) is a native species of Brazil occurring in the savanna (Cerrado) and Atlantic Coastal forests. It is a promising species for large-scale horticulture due to the high-protein properties of its fruits, but extensive cultivation has not yet been accomplished. Research is still needed to determine cultivation techniques that will optimize productivity. As irrigation is considered to be the most important agronomic technique to enhance productivity, the goal of this investigation was to evaluate the effects of irrigation on leaf gas exchange (net photosynthesis rate and transpiration rate) and foliar and fruiting phenology. Our results suggest that irrigation acts by increasing the growth and fruit production of mangabeira due to its effects on phenology. Gas exchange of adult plants was only marginally affected by irrigation; however, irrigated plants retained leaves longer than non-irrigated plants during the dry season, which increased the $\mathrm{C}$ gain over an annual period. The increase in $\mathrm{C}$ gain presumably led to irrigated plants having a higher relative frequency of fruited plants than the non-irrigated. A significant positive correlation between net photosynthesis rate per unit dry mass and specific leaf area was found for irrigated plants, which suggests that irrigation can promote the development of new leaf cells with no direct contribution to photosynthesis.

Key words: Hancornia speciosa, neotropical savanna, photosynthesis, specific leaf area

Fenologia de folhas e frutos e intercâmbio gasoso em Mangabeira em resposta à irrigação: A mangabeira (Hancornia speciosa Gómez) é uma espécie nativa do Brasil, distribuindo-se no Cerrado e nos Tabuleiros Costeiros e Baixadas Litorâneas. É uma espécie promissora para a horticultura nacional devido ao elevado teor protéico de seus frutos, mas seu cultivo extensivo ainda não está estabelecido. Ainda se necessitam pesquisas para determinarem-se técnicas de cultivo que resultem em aumento na produtividade. Como a irrigação é sabidamente a mais importante técnica agronômica para o aumento na produtividade, o objetivo deste estudo foi o de avaliar os efeitos da irrigação no intercâmbio gasoso (taxa fotossintética líquida e taxa transpiratória) e na fenologia de folhas e frutos. Os resultados obtidos sugerem que a irrigação possibilita o incremento no crescimento e na produção de frutos na mangabeira devido os seus efeitos sobre a fenologia. O intercâmbio gasoso das plantas adultas foi afetado apenas marginalmente pela irrigação; contudo, as plantas irrigadas retiveram suas folhas por mais tempo que as não irrigadas, durante a estação seca, o que determinou maior ganho anual de C. O incremento no ganho de C provavelmente determinou que as plantas irrigadas apresentassem maior freqüência relativa de plantas com frutos que as não irrigadas. Nas plantas irrigadas, verificou-se uma correlação positiva e significante entre a taxa fotossintética líquida expressa por unidade de massa e a área foliar específica, o que sugere que a irrigação pode promover o desenvolvimento de novas células que não contribuem diretamente com a fotossíntese nas folhas.

Palavras-chave: área foliar específica, fotossíntese, Hancornia speciosa, savana neotropical 


\section{INTRODUCTION}

The Brazilian savanna (Cerrado) is a biome of more than 200 million hectares, corresponding to approximately $22 \%$ of the country's land area (OliveraFilho and Ratter, 2002). Cerrado is extremely diverse, highly variable in physiognomy, and heavily impacted by agricultural activities such as cattle grazing and crop cultivation (Eiten, 1972). Average annual temperature and rainfall of the Cerrado region varies between $20-26^{\circ} \mathrm{C}$ and 750-2000 mm, respectively (Eiten, 1972; Olivera-Filho and Ratter, 2002); however, rainfall is highly seasonal with a 45 month dry season during which there may be no measurable rainfall (Rocha et al., 2002). The lack of rainfall causes soil moisture to decline rapidly leading to a prolonged period of drought (Nimer and Brandão, 1989; Franco, 2002).

Cerrado vegetation is considered to be "xeromorphic" due to the occurrence of seasonal drought (Eiten, 1972). Plants adapted to periodic drought exhibit a wide variety of responses to water stress, including declines in stomatal conductance, leaf area, and/or increases leaf senescence and abscission (Eamus, 1999; Franco, 2002; Meir and Grace, 2005). However, some Cerrado tree species reportedly have little ability to regulate stomatal conductance during drought, presumably because these species have deep root systems that have access to deep water reserves (Franco, 2002), while other trees species have shown considerable stomatal regulation even with access to deep water (Meinzer et al., 1999). Other plant species respond to seasonal drought by being deciduous or partially deciduous, which can increase water-use efficiency and promote re-hydration (Reich and Borchert, 1984; Borchert, 1994).

Hancornia speciosa Gómez (Apocynaceae), commonly known as mangabeira or mangaba, is a latexproducing tree that reaches heights of 5-7 $\mathrm{m}$ (Lorenzi, 2000). Mangabeira occurs in the Caatinga of the NE of Brazil, in the Cerrado of the central Brazilian states (e.g, Mato Grosso, Goiás, Tocantins, and Distrito Federal), and in Brazil's Atlantic Forest (Lorenzi, 2000; Olivera-Filho and Ratter, 2002). Mangabeira is common in nutrient-poor sandy soils, and responds to dry-season water deficit by being semi-deciduous (Lorenzi, 2000). Presumably the deciduous nature of mangabeira promotes re-hydration by reducing or preventing transpiration rate (Reich and Borchert, 1984; Borchert, 1994; Meinzer et al., 1999;
Franco, 2002); however, a decline in leaf area will also reduce carbon assimilation, growth, and productivity (Eamus, 1999; Meir and Grace, 2005).

Mangabeira is a potentially important horticultural crop due to international demand for exotic fruit, and its high-protein fruit is currently used for juice and in ice cream (Pereira Netto and McCown, 1999; Darrault and Schlindwein, 2005). However, there is currently limited commercial production of this species because little is known about cultivation techniques that could optimize productivity (Lederman and Bezerra, 2003; Nascimento, 2003). Given the drought-deciduous nature of mangabeira, irrigation may be a potentially useful means to enhance $\mathrm{C}$ gain and fruit production. Thus, the main objective of this research is to evaluate the effect of irrigation on leaf gas exchange and phenology of mangabeira plants, and to determine the potential of irrigation to increase leaf $\mathrm{CO}_{2}$ assimilation and fruit production.

\section{MATERIAL AND METHODS}

Experimental area: The experiment was carried out at the experimental farm $\left(15^{\circ} 47^{\prime} \mathrm{S} ; 56^{\circ} 04^{\prime} \mathrm{W}, 140 \mathrm{~m}\right.$ asl $)$ of the Mato Grosso Federal University, Mato Grosso State, Brazil. The farm is within the savanna (Cerrado) ecosystem and the soil is a Typic Plinthaquults.

The experimental area consisted of four plots of seven-year-old mangabeira (Hancornia speciosa Gómez) plants spaced in a $3 \times 3 \mathrm{~m}$ arrangement. Each plot had between 10-19 trees that were about $4.0 \mathrm{~m}$ tall with about $2.5 \mathrm{~m}$ canopy diameter when the experiment began in November 2004. Two of these plots were randomly assigned to receive irrigation and were irrigated daily only during the dry season using a drip irrigation system in order to maintain the soil moisture up to field capacity. The volume added to the irrigated plots was about $3 \mathrm{~L}$ per plant, while the non-irrigated plots just received ambient rainfall.

Depending on the variables measured, either all four plots or only two were measured (one irrigated and the other non-irrigated). For physiological variables only one irrigated plot and one non-irrigated plot was chosen, and for each plot, four plants were taken each as a replication. For phenological variables, all the four plots and all the plants inside each plot were taken into account. 
During the experiment, all the meteorological data, such as air temperature and humidity, rainfall, and Penman reference evapotranspiration, were monitored daily from a meteorological station located in the experimental farm.

Physiological variables: Four plants were chosen from one irrigated and one non-irrigated plot to be used in all the physiological measurements. All the physiological variables were taken from fully-expanded leaves that were exposed to full sunlight, usually being the fourth or fifth leaf counted from the apex of a branch located in the midthird of the canopy.

Stomatal conductance $\left(g_{\mathrm{s}}\right)$, net photosynthesis rate $(A)$, transpiration rate $(E)$, intercellular $\mathrm{CO}_{2}$ concentration $\left(C_{\mathrm{i}}\right)$, and atmospheric $\mathrm{CO}_{2}$ concentration $\left(C_{\mathrm{a}}\right)$ were measured with a portable photosynthesis system (LI6400, LI-COR, Inc., Lincoln, NE, USA). Using these variables, it was possible to calculate the $C_{\mathrm{i}} / C_{\mathrm{a}}$ ratio and the water-use efficiency ( $W U E$ ), expressed as $A / E$. Gas exchange measurements were made during the morning (0800-1100 h, local time) on April 16, October 7 and December 3 of 2005 and June 22 of 2006. These months were chosen as being representative of annual seasonality. April (autumn) represents the transition between the rainy and the dry seasons. October (spring) is very dry and hot and represents the end of the dry season. December (summer) is very rainy. June (winter) is dry but temperature is relatively low. Measurements on each leaf took approximately 3-5 min to be made, and gas exchange was calculated as an average of 10 measurements taken every $5 \mathrm{~s}$ which is the easiest way to avoid any possibility of spurious data being logged due to instantaneous equipment malfunction in field conditions. Measurements were made adjusting LI-6400 accessories (LI-6400-01, $\mathrm{CO}_{2}$ injector and LI-6400-02B light source) to provide a photosynthetic photon flux density of $1,000 \mu \mathrm{mol} \mathrm{m} \mathrm{m}^{-2} \mathrm{~s}^{-1}$, a $\mathrm{CO}_{2}$ concentration of 400

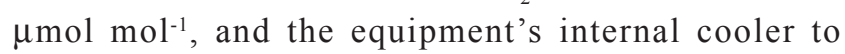
maintain a constant air temperature of $28^{\circ} \mathrm{C}$. During measurements, air relative humidity $(\mathrm{RH})$ and vapor pressure deficit (VPD) fluctuated according to the ambient, respectively $60 \%$ and $1.51 \mathrm{kPa}$ for April 2005, $25 \%$ and $2.83 \mathrm{kPa}$ for October $2005,80 \%$ and $0.76 \mathrm{kPa}$ for December 2005, and 70\% and $1.13 \mathrm{kPa}$ for June 2006 .
Specific leaf area $(S L A)$ was calculated as the leaf area (one-sided) divided by the respective dry mass, and was performed eight times from November, 2004 to June, 2006. Twenty leaves with the same characteristics of those used for gas exchange measurements were collected from each of the selected plants and photographed using a digital camera for the determination of leaf area using SigmaScan Pro. Harvested leaves were dried in a ventilated oven at $75^{\circ} \mathrm{C}$ for $48 \mathrm{~h}$, and the dry mass of each leaf was determined using a standard laboratory balance (0.1 mg precision). The $S L A$ for each plant was calculated as the mean value from the 20 measurements. The SLA was also employed to transform net photosynthesis rate expressed on a leaf area basis to that of leaf mass. In order to perform this transformation, only the first 10 leaves of the 20 were used. The remaining 10 leaves were used for a correlation analysis between $A$ expressed in both units (area and mass basis) and SLA, making these variables independent of each other.

Phenological variables: Every $15 \mathrm{~d}$ during the experimental period, the number of plants with expanded leaves, the number of plants with senescent leaves, and the number of plants with fruits in each of the two irrigated and the two non-irrigated plots were counted. The relative frequency of plants presenting these phenological characteristics was obtained as a percentage of the total number of plants. The two irrigated plots had 18 and 10 plants (total $=28$ ), and the two non-irrigated plots, 19 and 17 plants (total $=36$ ), respectively.

Experimental design and statistical analyses: The experiment was entirely randomized in a split-plot scheme to accommodate water regime as the main plot and time as the subplot, as described by Gomez and Gomez (1984) for measurement over time with plot sampling. For gas exchange variables, the experimental unit consisted of a single leaf sample taken from one selected plant. Four plants per treatment were employed as replications. For $S L A$, the experimental unit consisted of an average of the values obtained from 20 leaves per plant. All these leaves were at the same physiological age of those used for the gas exchange measurements. Phenological variables were only descriptive, and did not follow any experimental design. 


\section{RESULTS AND DISCUSSION}

Meteorological characteristics: The meteorological variables were typical for an Aw Köppen climate (Köppen, 1931). The warmest month occurred at the end of the dry season (August), although the wet season is warmer than the dry season, and the coldest month (July) is located in the middle of the dry season.

The most drastic variations of air temperature are typically observed in July-September during the dry season (Figure 1A). These months also have the lowest average daily relative humidity and the highest evapotranspiration, indicating the potential for the development of soil water deficit (Figure 1C,D). Despite the total rainfall for the study period being $2323 \mathrm{~mm}$ (Figure 1B), the total Penman reference evapotranspiration was $2550 \mathrm{~mm}$ (Figure 1D), illustrating the high atmospheric evaporative demand. Thus, the high evaporative demand and low rainfall suggests that irrigation of mangabeira during the dry season may be a good way to increase annual rates of primary production.

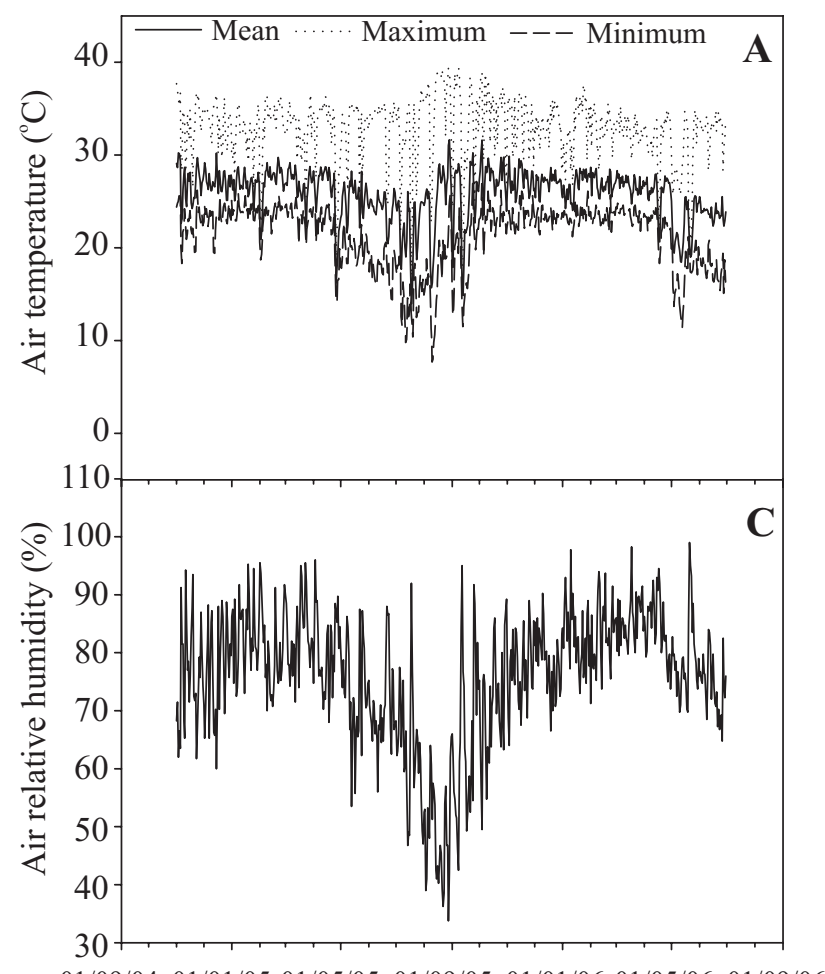

01/09/04 01/01/05 01/05/05 01/09/05 01/01/06 01/05/06 01/09/06
Physiological variables: Stomatal conductance $\left(g_{\mathrm{s}}\right)$ varied between $0.07-0.17 \mathrm{~mol} \mathrm{~m}^{-2} \mathrm{~s}^{-1}$ over the study period and there were no significant differences in $g_{\mathrm{s}}$ between seasons or irrigated and non-irrigated plants (Figure 2A). These data are consistent with the typical values reported for woody species (ca. 0.02-0.12 $\mathrm{mol} \mathrm{m}^{-2} \mathrm{~s}^{-1}$; Nobel, 1991). However, the lack of stomatal variation due to season or irrigation is in contrast to other savanna trees, which exhibit large seasonal variations in $g_{s}$ (Bucci et al., 2005; Domec et al., 2006; Monteiro and Prado, 2006). Considering the mean value of $g_{s}$ obtained for the mangabeira in this experiment $\left(0.129 \mathrm{~mol} \mathrm{~m}^{-2} \mathrm{~s}^{-1}\right)$, and the lack of stomatal control in response to seasonal drought and irrigation, it appears that the seasonal or experimental variations in water availability had little effect on $g_{s}$.

Leaf net photosynthesis rate $(A)$ varied significantly over time $(P=0.0022)$ but not in response to irrigation $(P=$ $0.7723)$ or to the interaction of these factors $(P=0.2877)$ (Figure 2B). In general, $A$ was highest in the wet season (April and December), and lowest in the dry season

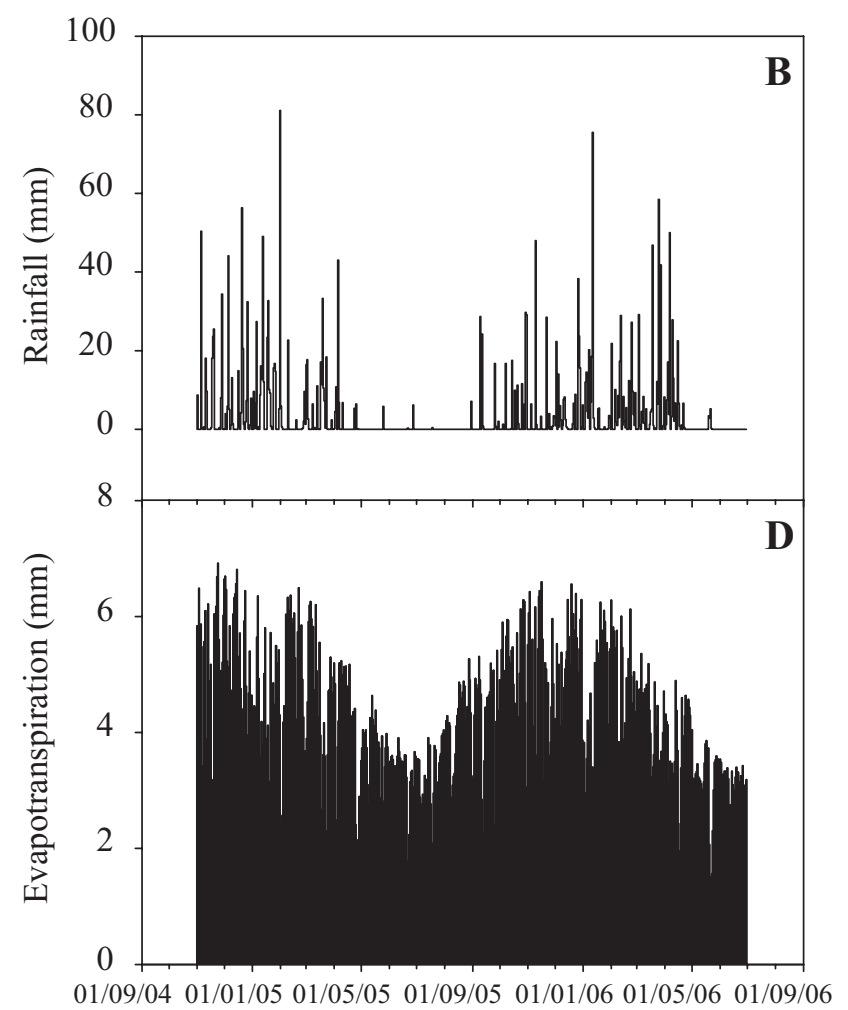

Date

Figure 1. Meteorological variables (A, air temperature; B, rainfall; C, relative humidity; D, evapotranspiration) from November 1, 2004 to June 30, 2006 at the experimental site. 
(October and June). The same pattern occurred with transpiration rate $(E)$, which varied significantly over time $(P=0.0003)$ but not with irrigation $(P=0.2924)$ or the interaction of these factors $(P=0.0758)$. However, $E$ followed a different temporal pattern than $g_{\mathrm{s}}$ and $A$. For example, the reductions in $g_{\mathrm{s}}$ and $A$ in October, although not statistically significant, occurred concomitantly with the highest value of $E$ (Figure 2). The difference between the $\mathrm{CO}_{2}$ and $\mathrm{H}_{2} \mathrm{O}$ vapor diffusion coefficients and the respective gas concentration gradient between leaf stomatal cavity and the boundary layer are the reasons that make this possible (Parkhurst, 1994).

The seasonal patterns of $A$ and $E$ led to a pattern of photosynthetic $W U E$ that varied significantly over time $(P=0.0001)$ but not as a function of irrigation regime $(P=$ $0.4123)$ or the interaction of these factors $(P=0.2530)$ (Figure 2D). The photosynthetic WUE was approximately $50-75 \%$ lower in October when rates of $E$ were high compared to other months.

The effect of the water regime on $C_{\mathrm{i}}$ and on $C_{\mathrm{i}} / C_{\mathrm{a}}$ was dependent on the time of sampling $(P=0.0301$, Figure $2 \mathrm{E}$ and $2 \mathrm{~F}$ ). However, we did not detect any significant difference among the mean values. It seems that gas exchange through stomata of mangabeira was limited to a particular $g_{s}$ that maintained a level of $C_{\mathrm{i}}$ that was more or less constant despite the meteorological variations in the year. Unfortunately, the water status of the plant was not measured in this experiment, preventing a deeper analysis of the possible mechanisms of the response of mangabeira to seasonal variations in drought and high evaporative demand. Nevertheless, the effect of water deficit on leaf gas exchange has been matter of controversy. Inter and intraspecific differences exist in plant resistance to drought, and variables commonly used to qualify the plant water status, such as leaf water potential or leaf relative water content, may not necessarily correlate with the photosynthetic variables. In an attempt to overcome this problem, Flexas and Medrano (2002) studied the relationships between $g_{s}$ and $A$ under light saturation conditions and concluded that $g_{s}$ is the variable that best explains the effect of water deficit on $A$ and that Rubisco activity declines when $g_{\mathrm{s}}$ is below $0.10 \mathrm{~mol} \mathrm{~m}^{-2} \mathrm{~s}^{-1}$. Taking this into consideration, the mangabeira would not present any evidence of water deficit compromising gas exchange.
Phenology: Mangabeira is a deciduous species and typically loses leaves during the dry season in August and September (Lorenzi, 2000). This seasonal pattern of leaf loss was observed for the non-irrigated plants (Figure 3A,C), however, irrigated plants had no abrupt leaf abscission. A simultaneous development of expanded and senescent leaves and a more homogeneous occurrence of senescent leaves were observed (Figure 3B,D). Plants of both treatments produced new leaves during the whole year; however, the relative frequency of plants with expanded (Figure 3B) and senescent (Figure 3D) leaves was higher for irrigated plants, especially during the transitional period between dry and wet seasons. In contrast, leaf production of non-irrigated plants coincided more with seasonal meteorological variations, with well-defined periods of high leaf production before the beginning of the rainy period and copious leaf abscission at the end of the wet season. Higher water availability in irrigated plots also increased the frequency of fruited plants, especially during the dry season (Figure 4).

It was found that $S L A$ was affected by the interaction between the irrigation regime and the time of sampling $(P$ $=0.0010)$. A significant difference was found between the $S L A$ for irrigated and non-irrigated trees in October $(P=$ $0.0032)$ but not in November $(P=0.0749)$ during the transition between the dry and wet seasons, and both groups of plants presented their highest $S L A$ value at that period of time. Both irrigated and non-irrigated plants reached their lowest value during the dry season when they did not differ from each other in April $(P=0.1000)$ and June $(P=0.1000)$ (Figure 5A). Similar trends for Bauhinia rufa, a deciduous species of the Brazilian neotropical savanna, were observed by Damascos et al. (2005) where foliar development was synchronized with the dry-wet season transition. Considering the SLA values for the period between November 1, 2004 and October 15, 2005, which is long enough to encompass the leaf life span, a tendency was observed for irrigated plants to have lower values of SLA than non-irrigated individuals during the period of new leaf formation in October and November. As the leaves aged, no difference was observed (Figure 5B). Although the ontogeny of leaves was not measured, non-irrigated plants lost the majority of their leaves during the dry season and produced new leaves during the dry-wet season 


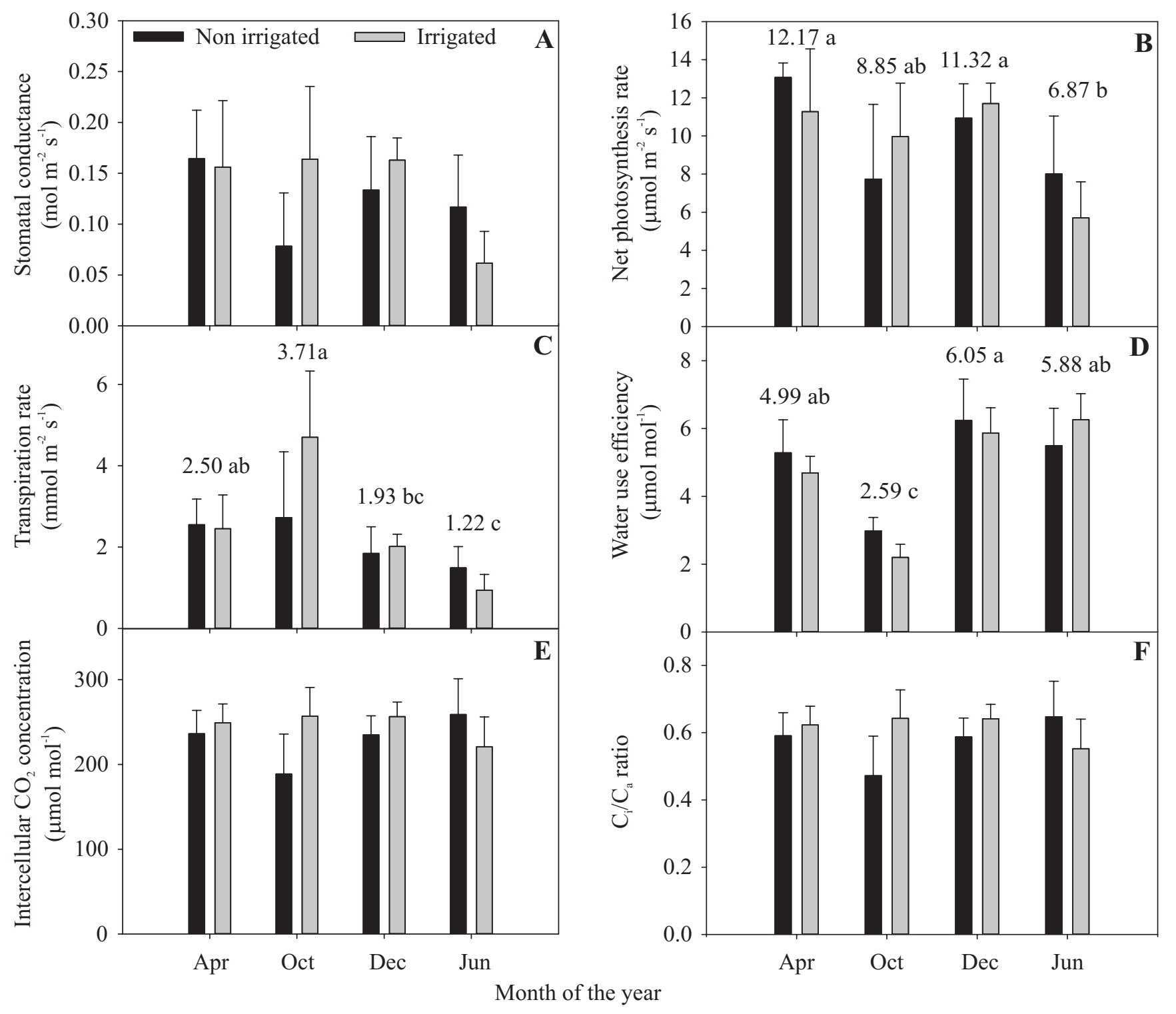

Figure 2. Stomatal conductance (A), net photosynthesis rate (B), transpiration rate (C), water use efficiency (D), intercellular $\mathrm{CO}_{2}$ concentration $(\mathbf{E})$, and the ratio of intercellular to ambient $\mathrm{CO}_{2}$ concentration $(\mathbf{F})$ of irrigated and nonirrigated mangabeira in April, October and December of 2005 and June of 2006 . Means $(n=4 \pm$ SE) of irrigated and non irrigated plants with the same letter do not differ $(P>0.05)$ from each other.

transition whereas irrigated plants did not display the synchronous abscission of leaves during the onset of the dry season (Figure 3). Thus, proportionally more leaves on irrigated trees were senescent during the drywet season transition compared to non-irrigated plants, and older leaves tend to have a lower SLA (Reich et al., 1992, 1998).

Although the temporal trends in $A$ and $S L A$ were similar, the correlation between $A$ and $S L A$ was weak when $A$ was expressed per unit of leaf area. But there was a significant correlation between $A$ and $S L A$ for irrigated plants when $A$ was expressed per unit dry mass (Figure 6). This result suggests that irrigation can promote the development of cells with little photosynthetic participation in mangabeira plant leaves, but maybe with other functional activity. 


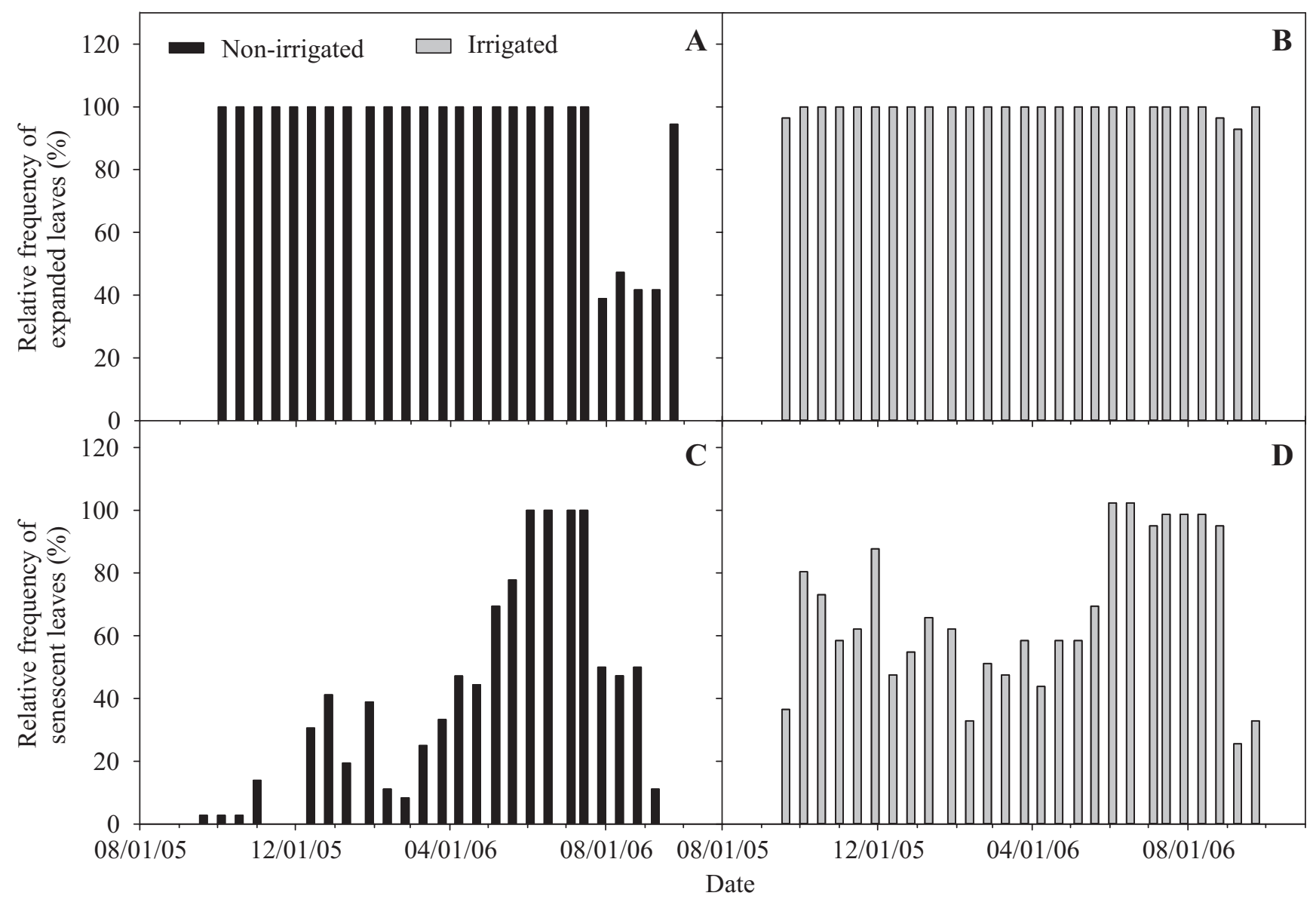

Figure 3. Relative frequency of mangabeira plants with expanded leaves (A and $\mathbf{B}$ for non-irrigated and irrigated treatments, respectively) and with senescent leaves ( $\mathbf{C}$ and $\mathbf{D}$ for non-irrigated and irrigated treatments, respectively) during the period of September 20, 2005 to September 23, 2006.

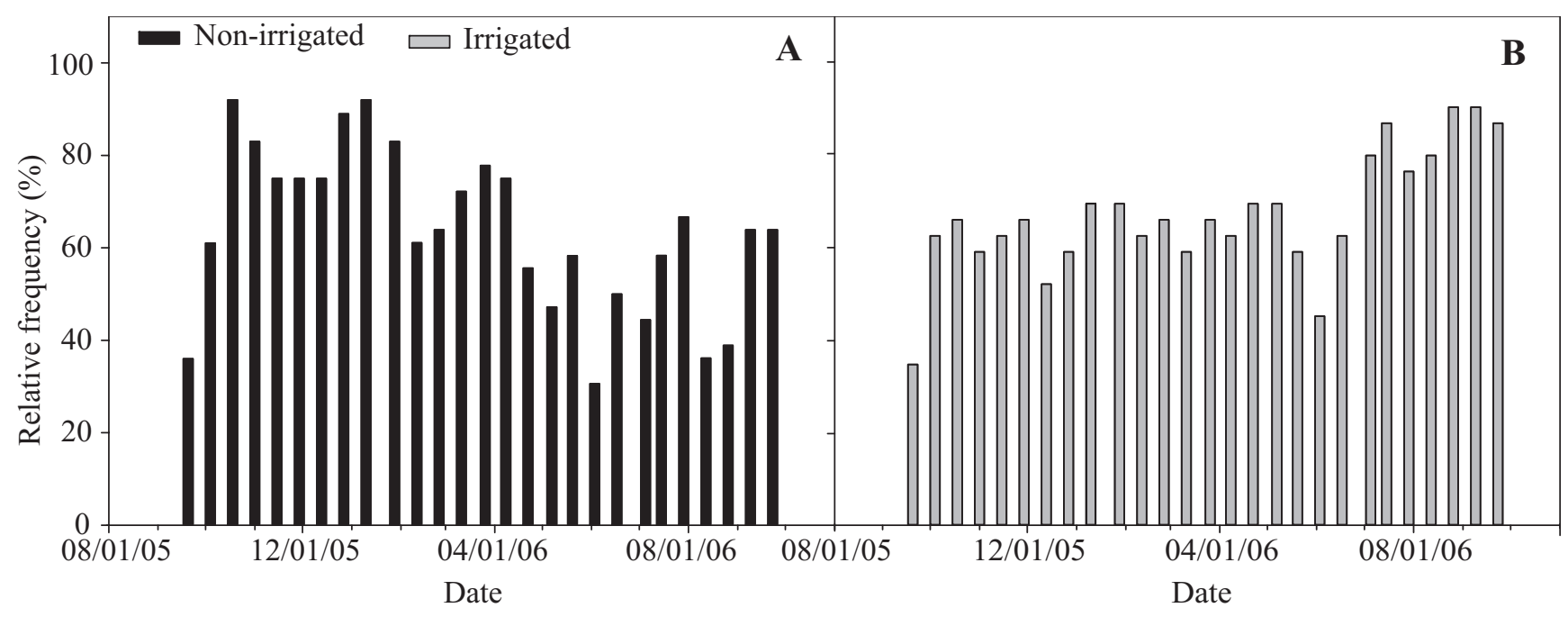

Figure 4. Relative frequency of fruited mangabeira plants in non-irrigated (A) and irrigated (B) treatments during the period of September 20, 2005 to September 23, 2006. 

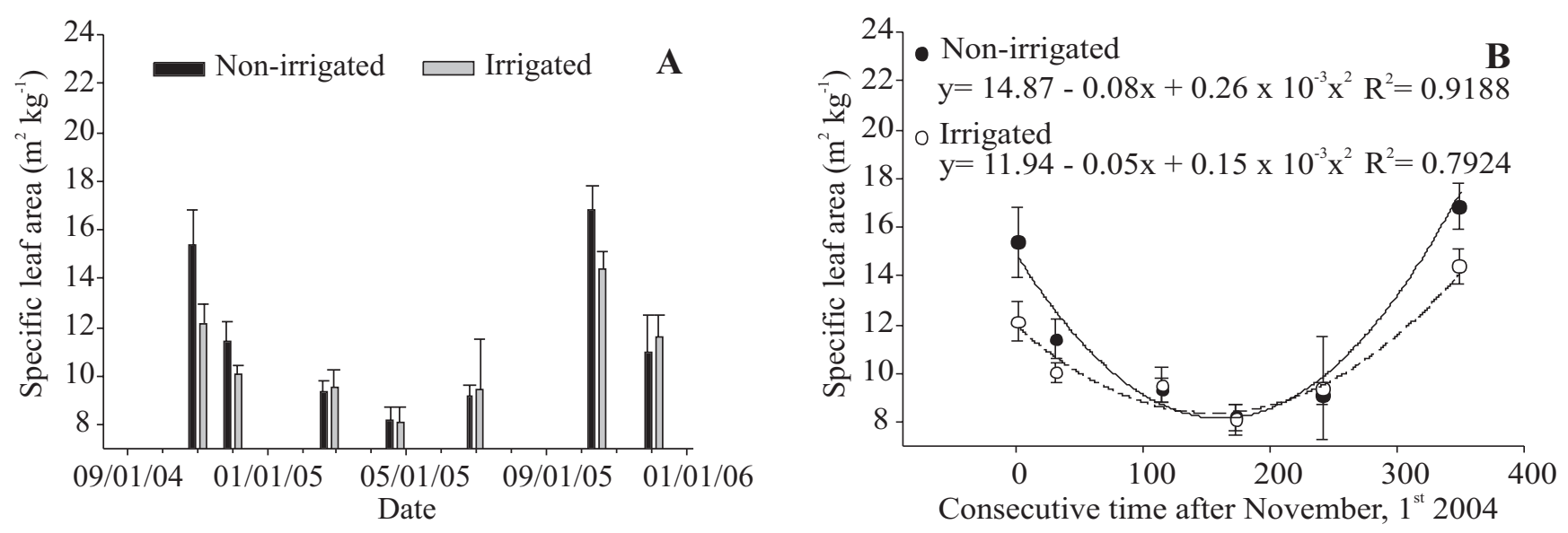

Figure 5. Effect of irrigation on specific leaf area $(n=4 \pm \mathrm{SE})$ for mangabeira plants during the period of November of 2004 to June of 2006 at the experimental site.

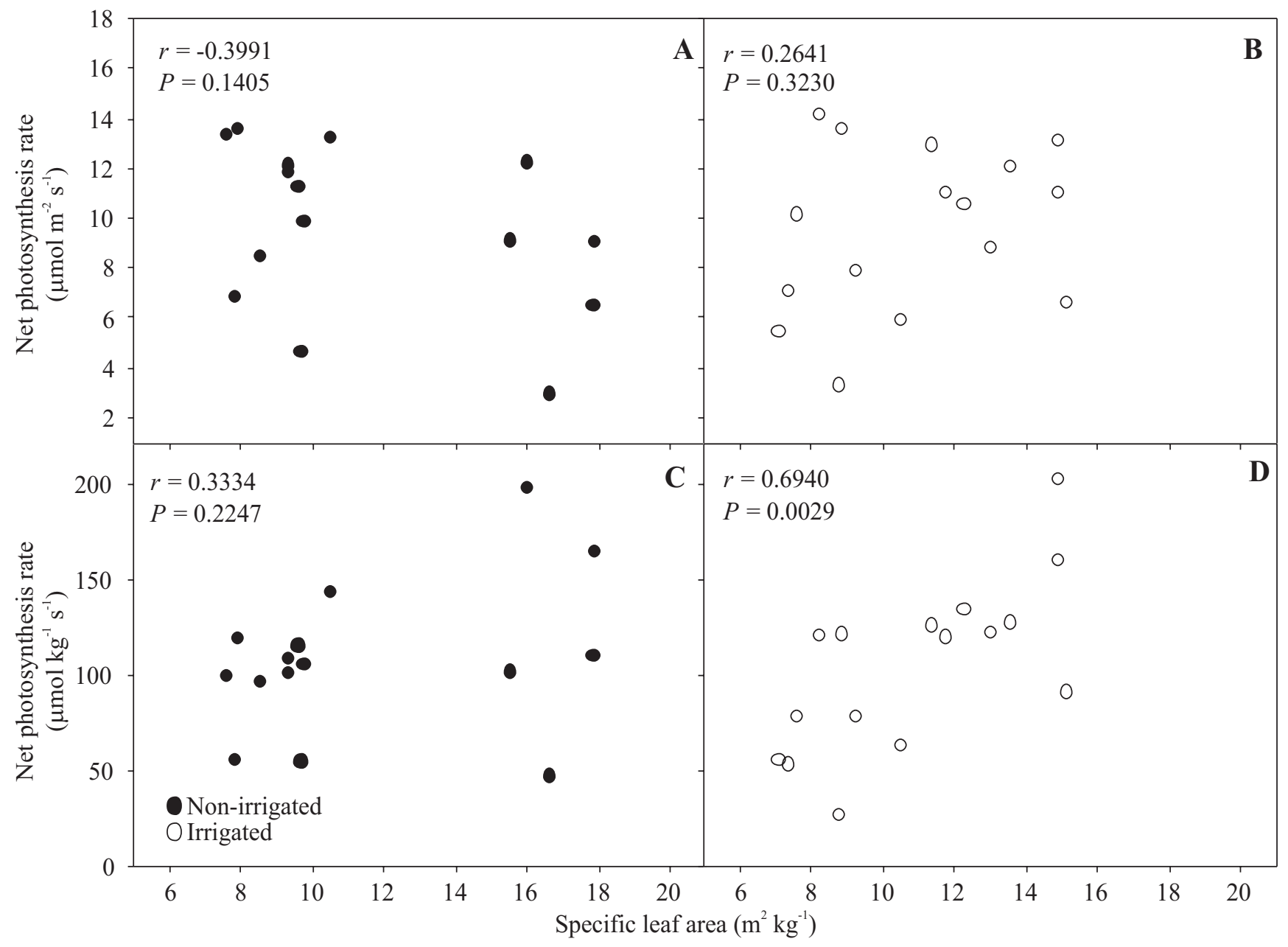

Figure 6. Correlation between specific leaf area and net photosynthetic rate expressed per unit leaf area (A and $\mathbf{B}$ for non-irrigated and irrigated treatments, respectively) or per unit leaf mass ( $\mathbf{C}$ and $\mathbf{D}$ for non-irrigated and irrigated treatments, respectively). 


\section{CONCLUSIONS}

Irrigation marginally affected gas exchange in adult mangabeira plants; however, the effect of irrigation was amplified by differences in foliar and fruiting phenology. Irrigation caused higher frequency of plants with expanded leaves especially during the dry season. Senescence and abscission occurred much more uniformly along the year in irrigated plants while nonirrigated plants presented defined periods of new leaf production and abscission of old leaves. Irrigation also increased the frequency of fruited plants, especially during the dry season.

The specific leaf area was apparently not directly affected by irrigation, but changed with foliar ontogeny, decreasing as leaves aged. There were significant differences between irrigated and non-irrigated plants during the transition from dry to wet seasons. Irrigated plants presented a significant correlation between net photosynthesis rate per unit dry mass and specific leaf area, suggesting that the development of new leaf cells with no direct effects on photosynthesis are promoted by irrigation.

Acknowledgements: The authors thank the National Council of Technological and Scientific Development $(\mathrm{CNPq})$ for the scientific initiation scholarship awarded to Isabela C. de Lucena.

\section{REFERENCES}

Borchert R (1994) Soil and stem water storage determine phenology and distribution of tropical dry forest trees. Ecology 75:1437-1449.

Bucci SJ, Goldstein G, Meinzer FC, Franco AC, Campanelo P, Scholz FG (2005) Mechanisms contributing to seasonal homeostasis of minimal leaf water potential and predawn disequilibrium between soil and plant water potential in Neotropical savanna trees. Trees 19:296-304.

Damascos MA, Prado CHBA, Ronquim CC (2005) Bud composition, branching patterns and leaf phenology in Cerrado wood species. Ann. Bot. 96:1075-1084.

Darrault RO, Schlindwein C (2005) Limited fruit production in Hancornia speciosa (Apocinaceae) and pollination by nocturnal and diurnal insects. Biotropica 37:381-388.
Domec JC, Scholz FG, Bucci SJ, Meinzer FC, Goldstein G, Villalobos-Vega R (2006) Diurnal and seasonal variation in root xylem embolism in neotropical savanna wood species: impact on stomatal control of plant water status. Plant Cell Environ. 29:26-35.

Eamus D (1999) Ecophysiological traits of deciduous and evergreen woody species in the seasonally dry tropics. Trends Ecol. Evol. 14:11-16.

Eiten G (1972) The cerrado vegetation of Brazil. Bot Rev. 38:201-341.

Flexas J, Medrano H (2002) Drought-inhibition of photosynthesis in $\mathrm{C}_{3}$ plants: stomatal and nonstomatal limitations revisited. Ann. Bot. 89:183-189.

Franco AC (2002) Ecophysiology of woody plants. In: Oliveira PS, Marquis RJ (eds), The Cerrados of Brazil. Ecology and Natural History of a Neotropical Savanna, pp.178-200. Columbia University Press, New York.

Köppen W (1931) Grundriss der Klimakunde. (Zweite, verbesserte Auflage der Klimate der Erde.). Walter de Gruyter \& Co., Berlin.

Lederman IE, Bezerra JEF (2003) Situação atual e perspectivas da cultura mangaba no Brasil. In: Anais do Simpósio Brasileiro sobre a Cultura da Mangaba. Embrapa Tabuleiros Costeiros, Aracaju, Brazil.

Lorenzi H (2000) Hancornia speciosa Gomez. In: Lorenzi H (ed), Árvores Brasileiras. Manual de Identificação e Cultivo de Plantas Arbóreas Nativas do Brasil, Vol. 1, pp.28. Instituto Plantarum de Estudos da Flora, Nova Odessa.

Meir P, Grace J (2005) The response of drought by tropical rainforest ecosystems. In: Malhi Y, Grace J (eds), Tropical Forests and Global Atmospheric Change, pp.75-84. Oxford University Press, Oxford.

Meinzer FC, Goldstein G, Franco AC, Bustamante M, Igler E, Jackson P, Caldas L, Rundel PW (1999) Atmospheric and hydraulic limitations on transpiration in Brazilian cerrado woody species. Funct. Ecol. 13:273-282.

Monteiro JAF, Prado CHBA (2006) Apparent carboxylation efficiency and relative stomatal and mesophyll limitations of photosynthesis in an evergreen Cerrado species during water stress. Photosynthetica 44:39-45.

Nascimento $\mathrm{S}$ da $\mathrm{S}$ (2003) Fomento à produção e à pesquisa da mangabeira e outras frutas potenciais. Anais do Simpósio Brasileiro sobre a Cultura da Mangaba. Embrapa Tabuleiros Costeiros, Aracaju, Brazil. 
Nimer E, Brandão AMPM (1989) Balanço Hídrico e Clima da Região dos Cerrados. Fundação Instituto Brasileiro de Geografia e Estatística, Rio de Janeiro.

Nobel PS (1991) Physicochemical and Environmental Plant Physiology, Academic Press, San Diego.

Oliveira FilhoAT, Ratter JA (2002) Vegetation physiognomies and woody flora of the cerrado biome. In: Oliveira PS, Marquis RJ (eds), The Cerrados of Brazil. Ecology and Natural History of a Neotropical Savanna, pp.91-120. Columbia University Press, New York.

Parkhurst DF (1994) Diffusion of $\mathrm{CO}_{2}$ and other gases inside leaves. New Phytol. 126:449-479.

Pereira Netto AB de, McCown BH (1999) Thermally induced changes in morphology of Hancornia speciosa microcultures: evidation of mediation by ethylene. Tree Physiol. 19:733-740.
Reich PB, Borchert R (1984) Water stress and tree phenology in a tropical dry forest in the lowlands of Costa Rica. J. Ecol. 72:61-74.

Reich PB, Walters MB, Ellsworth DS (1992) Leaf life-span in relation to leaf, plant, and stand characteristics among diverse ecosystems. Ecol. Monogr. 62:365-392.

Reich PB, Walters MB, Tjoelker MG, Vanderklein D, Buschena C (1998) Photosynthesis and respiration rates depend on leaf and root morphology and nitrogen concentration in nine boreal tree species differing in relative growth rate. Funct. Ecol. 12:395405.

Rocha HR, Freitas HC, Rosolem R, Juarez RIN, Tannus RN, Ligo MA, Cabral OMR, Silva Dias MAF (2002) Measurements of $\mathrm{CO}_{2}$ exchange over a woodland savanna (Cerrado sensu stricto) in southeast Brazil. Biota Neotrop. 2:1-11. 